Nama : Rhosika Amaliah Rauf

Nim : 70200119110

Tugas Remedial Final Test

\title{
PENGUATAN KADER KESEHATAN MELALUI EDUKASI GIZI DALAM MENGATASI ANEMIA PADA IBU HAMIL
}

\section{PENDAHULUAN}

Anemia pada ibu hamil menjadi masalah di dunia, karena anemia pada ibu hamil sangat erat kaitannya dengan mortalitas dan morbiditas pada ibu dan bayi termasuk resiko keguguran, lahir mati, rematuritas, berat bayi lahir rendah (WHO 2014). Anemia pada ibu hamil sangat berpengaruh terhadap kualitas manusia yang akan dilahirkan dan kualitas sumber daya manusia (SDM) generasi yang akan datang. Selain itu, anemia pada ibu hamil dapat meningkatkan kejadian abortus, prematus, berat badan lahir rendah (BBLR), serta dapat menyebabkan kematian pada ibu hamil pada waktu dan sesudah melahirkan (Syarfaini et al., 2020). Anemia merupakan masalah yang dialami oleh $41,8 \%$ ibu hamil di dunia. Sekitar setengah dari kejadian anemia tersebut disebabkan karena defisiensi besi. Adapun prevalensi anemia pada ibu hamil di dunia yaitu diperkirakan Afrika sebesar 57,1\%, Asia 48,2\%, Eropa 25,1\% dan Amerika $24,1 \%$ (WHO 2015).

Data World Health Organization (WHO) tahun 2010 menyebutkan bahwa 40\% penyebab kematian ibu di negara berkembang berkaitan dengan anemia dalam kehamilan. Anemia dalam kehamilan merupakan masalah kesehatan yang utama di negara berkembang dengan tingkat kesakitan tinggi pada ibu hamil. Total penderita anemia pada ibu hamil di Indonesia adalah $70 \%$, artinya dari $10 \mathrm{ibu}$ hamil, sebanyak 7 orang akan menderita anemia. Menurut data Riset Kesehatan Dasar pada tahun 2013, prevalensi anemia ibu hamil di Indonesia sebesar 37\% mengalami peningkatan dari tahun 2007 sebanyak 24,5\% (Kemenkes RI, 2014).

Tingginya prevalensinya anemia pada ibu hamil merupakan masalah yang tengah dihadapi pemerintah Indonesia (Kemenkes RI, 2014). Angka kematian ibu (AKI) atau maternal mortality rate (MMR) mencerminkan risiko yang dihadapi ibu-ibu selama kehamilan dan melahirkan yang dipengaruhi oleh status gizi ibu, keadaan sosial ekonomi, keadaan kesehatan yang kurang baik menjelang kehamilan, kejadian berbagai komplikasi pada kehamilan dan kelahiran, tersedianya dan penggunaan fasilitas pelayanan kesehatan ternasuk pelayanan prenatal dan obstetri (Purwaningtyas dan Prameswari, 2017). 
Penanganan anemia pada ibu hamil merupakan salah satu agenda penting dalam pembangunan nasional karena anemia terkait langsung dengan kesehatan masyarakat yaitu kesehatan ibu. Pemeliharaan dan perawatan kesejahteraan ibu merupakan suatu strategi dalam upaya pemenuhan pelayanan dasar yang meliputi peningkatan derajat kesehatan dan gizi yang baik serta deteksi dini terhadap penyakit (Solehati et al., 2018).

Prevalensi kejadian anemia pada ibu hamil disebabkan oleh beberapa faktor langsung dan tidak langsung, diantaranya adalah tingkat pendidikan,status ekonomi dan konsumsi oleh ibu. Berdasarkan hasil penelitian Nila Krisnawati, tingkat pendidikan, tingkat pengetahuan dan tingkat konsumsi zat besi memiliki hubungan signifikan dengan terjadinya anemia (Krisnawati, 2010).

Pola konsumsi individu merupakan salah satu faktor penyebab langsung terhadap keadaan status gizi dan status kesehatan pada wanita usia subur. Jika jumlah pola konsumsi makanan selama satu hari tidak sesuai dengan pola gizi seimbang dan tidak sesuai dengan kebutuhan gizi individu, maka pola konsumsi tersebut terukur dalam kategori kurang baik. Gizi seimbang merupakan suatu susunan makanan sehari-hari yang mengandung zat-zat gizi dalam jenis dan jumlah yang sesuai dengan kebutuhan tubuh dan terpenuhi, dengan memerhatikan prinsip variasi makanan atau keanekaragaman, kebersihan, aktivitas fisik, dan berat badan ideal (Supariasa et al., 2002).

Anemia yang sering terjadi pada ibu hamil adalah anemia karena defisiensi besi (Fe) atau disebut dengan anemia gizi besi (AGB). Sekitar 95\% kasus anemia selama kehamilan adalah karena kekurangan zat besi. Pendapatan keluarga merupakan penyebab pola konsumsi masyarakat kurang baik, tidak semua masyarakat dapat mengkonsumsi lauk hewani dalam makanan. Keanekaragaman konsumsi makanan berperan penting dalam membantu meningkatkan penyerapan Fe di dalam tubuh. Pengetahuan dan pendidikan yang dimiliki oleh seorang ibu akan mempengaruhi pengambilan keputusan dalam memberikan gizi yang cukup bagi ibu dan bayinya serta lebih mudah menerima informasi sehingga dapat mencegah dan mengatasi anemia pada masa kehamilan. Asupan zat besi dan protein yang kurang akibat tidak mengkonsumsi makanan yang mengandung zat besi dapat menyebabkan anemia defisiensi besi (Kristiyanasari, 2010).

Menurut Sulistyaningsih dan Yuliyanti (2017), untuk mengatasi anemia pada ibu hamil diperlukan suatu upaya tambahan yaitu edukasi mengenai gizi pada ibu hamil dengan anemia yang terbukti dapat meingkatkan kadar hemoglobin ibu. 


\section{Status Gizi ibu Hamil}

Status gizi dan kesehatan ibu pada masa pra-hamil, saat kehamilan dan saat menyusui merupakan periode yang sangat penting yang menentukan kualitas sumber daya manusia nantinya. Periode ini dikenal dengan periode 1000 Hari Pertama Kehidupan (HPK) manusia yang dihitung dari 270 hari selama kehamilan dan 730 hari pada kehidupan pertama bayi yang dilahirkan (sampai anak berusia 2 tahun). Masa ini merupakan periode sensitif karena akibat kekurangan asupan gizi yang ditimbulkan terhadap bayi pada masa ini akan bersifat permanen dan tidak dapat diperbaiki. Dampak tersebut tidak hanya pada pertumbuhan fisik, tetapi juga pada perkembangan mental dan kecerdasannya, yang pada usia dewasa terlihat dari ukuran fisik yang tidak optimal serta kualitas kerja yang tidak kompetitif sehingga produktivitas ekonomi menjadi rendah.

Nutrisi selama kehamilan adalah salah satu faktor penting dalam pembentukan janin. Pola makan yang baik akan cukup menyediakan gizi yang dibutuhkan untuk kesehatan selama kehamilan dan mengurangi risiko lahirnya baayi cacat. Selain itu makanan yang baik akan membantu sistem pertahanan tubuh ibu hamil terhadap terjadinya infeksi. Makanan yang baik juga akan melindungi ibu hamil dari akibat buruk zat-zat yang mungkin ditemui seperti obatobatan, toksin, dan polutan. Asupan makanan selama hamil berbeda dengan asupan sebelum masa kehamilan untuk memenuhi kebutuhan ibu dan janin, berdasarkan Angka Kecukupan Gizi (AKG).

Gizi ibu hamil adalah makanan atau zat gizi (baik makro maupun mikro) yang dibutuhkan oleh seorang ibu hamil baik padaa trimester I, trimester II dan trimester III serta harus mencukupi jumlah yang dibutuhkan, mutu yang dapat dipenuhi dari kebutuhan seharihari sehingga janin yang dikandungnya dapat tumbuh dengan baik serta tidak memiliki gangguan. Ibu yang hamil harus memiliki gizi yang cukup, karena gizi yang didapat akan digunakan untuk dirinya dan janinnya. Seorang ibu yang tidak memiliki ataupun kekurangan gizi selama awal kehamilan, maka bayi yaang dikandungnya akan menderit kekurangan gizi.

Selama kehamilan, secara fisiologis ibu hamil akan mengalami perubahan. Perubahan yang dialami seorang ibu hamil meliputi perubahan sistem reproduksi, sistem perkemihan, sistem pencernaan, sirkulasi darah, kulit, metabolisme, sistem pernafasan, dan penambahan berat badan. Perubahan fisiologis pada ibu hamil akan mempengaruhi perubahan kebutuhan gizi ibu hamil. (Simbolon, 2018)

Perubahan kebutuhan gizi ibu hamil tergantung dari kondisi kondisi kesehatan ibu. Kusmiyati (2009) mengungkapkan dasar pengaturan gizi ibu hamil adalah adanya penyesuaian selama kehamilan yaitu, sebagai berikut: 
1. Peningkatan basal metabolisme dan kebutuhan kalori. Metabolisme basal pada masa 4 bulan pertama mengalami peningkatan kemudian menurun 20-25\% pada 20 minggu terakhir.

2. Perubahan fungsi alat pencernaan karena perubahan hormonal, peningkatan HCG, esterogen, progesteron menimbulkan berbagai perubahan seperti mual muntah, motilitas lambung sehingga penyerapan makanan lebih lama, peningkatan absorbsi nutrien, dan motilitas usus sehingga timbul masalah obstipasi.

3. Peningkatan fungsi ginjal sehingga banyak cairan yang dieksresi pada pertengahan kehamilan dan sedikit cairan diekskresi pada bulan-bulan terakhir kehamilan.

4. Peningkatan volume dan plasma daraah hingga 50\% jumlah erytrosit $20-30 \%$ sehingga terjadi penurunan hemodilusi dan konsentrasi hemoglobin.

Kebutuhan gizi pada ibu hamil yang terpenuhi dalam makanan sehari-hari akan berpengaruh pada tumbuhan dan perkembangan bayi, janin dalam kandungan dapat tumbuh dengan baik serta tidak mengalami gangguan dan masalah. Asupan makanan yang dikonsumsi oleh ibu hamil berguna untuk pertumbuhan dan perekmbangan janin, mengganti sel-sel tubuh yang rusak atau mati, sumber tenaga, mengatur suhu tubuh dan cadangan makanan. Kebutuhan selama hamil yang berbeda-beda untuk setiap individu dan juga dipengaaruhi oleh riwayat kesehatan dan status gizi ibu sebelumnya (Simbolon, 2018).

\section{Faktor Kejadian Anemia Pada Ibu Hamil}

Banyak faktor yang memengaruhi terjadinya anemia kehamilan di antaranya faktorfaktor yang berhubungan dengan kejadian anemia pada ibu hamil, yaitu :

1. Umur kehamilan

Kebutuhan zat besi selama kehamilan menunjukkan peningkatan seiring bertambahnya umur kehamilan. Kebutuhan zat besi pada 18 minggu pertama kehamilan tidak menunjukkan peningkatan sehingga masukan dari makanan sebesar 11-13 mg/hari telah mampu mencukupi kebutuhan tersebut. Setelah 20 minggu, massa eritrosit ibu mulai bertambah dan fetus membutuhkan lebih banyak zat besi. Kebutuhan zat besi menunjukkan peningkatan tajam selama trimester dua dan khususnya trimester tiga. Morisson and Marc (2011) mengemukakan bahwa kebutuhan harian zat besi di trimester tiga 4,1 mg lebih tinggi dibandingkan kebutuhan sebelum hamil yaitu sebesar 5,6 mg/hari (3,54- 8,80 mg/hari).

Peningkatan kebutuhan zat besi pada ibu hamil tersebut tidak dapat dipenuhi hanya dari makanan, bahkan makanan yang telah mengalami fortifikasi zat besi juga tidak mampu memenuhi kebutuhan ini. Oleh karenanya pemenuhan zat besi saat hamil juga tergantung pada dua faktor yaitu cadangan zat besi sebelum hamil dan suplemen zat besi selama kehamilan. Anemia pada kehamilan di TM III dihubungan dengan peningkatan umur 
kehamilan yang menyebabkan ibu semakin lemah dan zat besi di dalam darah dibagi untuk pertumbuhan fetus di dalam rahim sehingga mengurangi kapasitas pengikatan zat besi di dalam darah ibu. Ibu hamil harus mengonsumsi makanan yang bergizi diimbangi dengan suplementasi TTD untuk mengompensasi hemodilusi yang terjadi ( Prahesti, 2017).

2. Antenatal Care (ANC)

Masa kehamilan merupakan masa yang rawan kesehatan, baik kesehatan ibu yang mengandung ataupun janin sehingga dalam masa kehamilan perlu dilakukan pemeriksaan secara teratur. Hal ini dilakukan untuk menghindari gangguan sedini mungkin dari segala sesuatu yang membahayakan kesehatan ibu dan janin (Kemenkes RI, 2013). Kunjungan ibu hamil dalam memeriksakan kehamilan berpengaruh terhadap kejadian anemia. Hal tersebut sesuai dengan tujuan ANC yaitu mengenali secara dini adanya ketidaknormalan atau komplikasi yang mungkin terjadi selama hamil, termasuk riwayat penyakit secara umum, kebidanan, dan pendarahan (Prawirohardjo, 2007). Kunjungan ibu hamil yang sesuai standar akan memberikan kemudahan tenaga kesehatan (dokter dan bidan) untuk mendeteksi kelainan-kelainan yang akan timbul setiap saat termasuk kejadian anemia.

3. Usia Ibu

Usia seorang perempuan dapat memengaruhi emosi selama kehamilannya. Usia antara 20-35 tahun merupakan periode yang paling aman untuk melahirkan. Ibu hamil di atas usia 35 tahun cenderung mengalami anemia disebabkan karena pengaruh turunnya cadangan zat besi dalam tubuh. Pada kehamilan pertama pada wanita berusia di atas 35 tahun juga akan memunyai risiko penyulit persalinan dan mulai terjadinya penurunan fungsi-fungsi organ reproduksi (Proverawati, 2011). Seorang wanita yang hamil pada rentang usia 20-35 tahun akan lebih sehat karena masih dalam usia reproduktif.

4. Pendidikan

Pendidikan meliputi peranan penting dalam menentukan kualitas manusia. Dengan pendidikan manusia dianggap akan memperoleh pengetahuan. Semakin tinggi pendidikan, hidup manusia akan semakin berkualitas karena pendidikan yang tinggi akan membuahkan pengetahuan yang baik yang menjadikan hidup yang berkualitas. Tingkat pendidikan seseorang akan berpengaruh dalam pemberian respon terhadap sesuatu yang datangnya dari luar. Orang yang berpendidikan tinggi akan memberikan respon yang lebih rasional terhadap informasi yang datang dan akan berpikir sejauh mana keuntungan yang akan mereka dapatkan (Mubarak, 2007). Orang yang tidak berpendidikan tinggi akan memberikan respon yang kurang rasional dan dalam pengambilan keputusan. 
Seorang ibu khususnya ibu hamil yang memiliki pendidikan tinggi dapat menyeimbangkan pola konsumsinya. Apabila pola konsumsinya sesuai maka asupan zat gizi yang diperoleh akan tercukupi, sehingga dapat terhindar dari masalah anemia (Marmi dan Raharjo, 2012). Apabila ibu hamil tidak dapat memilih asupan zat gizi yang bagus untuk tumbuh kembang janin, maka dapat terjadi anemia atau komplikasi lain.

5. Pendapatan Keluarga

Di negara berkembang dengan kondisi pendapatan masyarakat yang rendah, faktor yang berkontribusi terhadap anemia adalah kurangnya konsumsi makanan yang mengandung zat besi terutama zat besi dari daging. Daging adalah sumber protein yang berkuatitas, zat besi, zinc, dan vitamin B kecuali asam folat. Meskipun demikian makanan tidaklah satu-satunya faktor yang berpengaruh terhadap anemia, karena anemia juga dapat dipengaruhi oleh tingkat absorbsi zat besi dalam tubuh (Jufar and Tewabech, 2014). Tingkat absorbsi dalam tubuh antara satu dengan ibu hamil lainnya berbeda karena dipengaruhi oleh banyak faktor.

6. Paritas dan Jarak Kehamilan

Salah satu yang memengaruhi anemia adalah jumlah anak dan jarak antar kelahiran yang dekat (Tarwoto dan Wasnidar, 2007). Di negara yang sedang berkembang terutama di daerah pedesaan, ibu-ibu yang berasal dari tingkat sosial ekonomi yang rendah dengan jumlah anak yang banyak dan jarak kehamilan dekat serta masih menyusui untuk waktu yang panjang tanpa memperhatikan gizi saat laktasi akan sangat berbahaya bagi kelangsungan hidupnya dan sering sekali menimbulkan anemia.

7. Kepatuhan konsumsi tablet tambah darah

Kepatuhan konsumsi tablet tambah darah sangat penting dalam keberhasilan pengobatan anemia. Kepatuhan adalah menurut perintah, taat pada perintah atau aturan, dan berdisiplin (Depdiknas, 2008).

Tablet tambah darah sering disebut tablet zat besi. Zat besi merupakan mineral yang diperlukan oleh semua sistem biologi di dalam tubuh. Zat besi adalah komponen dari hemoglobin, mioglobin, enzim katalase, serta peroksidase. Besi merupakan mineral mikron yang paling banyak terdapat di dalam tubuh manusia dewasa (Almatsier, 2009).

Wanita hamil merupakan salah satu kelompok yang diprioritaskan dalam program suplementasi. Dosis suplementasi yang dianjurkan dalam satu hari adalah dua tablet (satu tablet mengandung $60 \mathrm{mg}$ besi dan $200 \mathrm{mg}$ asam folat) yang diminum selama paruh kedua kehamilan karena pada saat tersebut kebutuhan akan zat besi sangat tinggi (Depkes RI, 2012). Pemberian tablet tambah darah merupakan program pemerintah yaitu dengan jumlah 
pemberian 90 tablet selama kehamilan (Wiknjosastro, 2006). Tablet tambah darah yang menjadi program pemerintah ini mengandung komposisi Ferro Sulfat 200 mg (setara dengan besi elemen $60 \mathrm{mg}$ ), Asam Folat 0,25 mg dengan kemasan isi 30 tablet pada setiap bungkusnya.

\section{Anemia Pada Kehamilan}

Anemia kehamilan didefinisikan WHO sebagai kadar hemoglobin kurang dari 11g/dl atau hematokrit kurang dari $33 \%$ pada setiap waktu pada kehamilan (Sharma and Meenakshi, 2010). Definisi anemia kehamilan oleh WHO ini berbeda dengan definisi oleh Center for Disease Control and Prevention (CDC). Definisi anemia kehamilan oleh CDC (2012) mempertimbangkan hemodilusi yang normal terjadi dalam kehamilan di mana kadar hemoglobin kurang dari $11 \mathrm{~g} / \mathrm{dl}$ pada trimester pertama dan ketiga, dan kurang dari 10,5 g/dl pada trimester kedua (Creasi et al, 2009). Dengan adanya batas anemia yang berbeda pada trimester II dan lainnya, maka setiap hasil pemeriksaan perlu melihat standar batas anemia yang telah ditentukan.

Menurut Proverawati (2011) anemia merupakan suatu kumpulan gejala yang disebabkan oleh bermacam-macam penyebab. Terjadinya anemia karena adanya beberapa faktor yang saling berkaitan. Pada dasarnya anemia disebabkan oleh karena gangguan pembentukan eritrosit oleh sumsum tulang belakang, kehilangan darah keluar tubuh (pendarahan), dan proses penghancuran erirosit dalam tubuh sebelum waktunya (hemolisis), faktor nutrisi, infeksi, dan pengaruh genetik (Masukume et al, 2015). Penyebab anemia yang lain antara lain pendarahan misalnya ulkus, gastritis, tumor saluran pencernaan, malabsorpsi, kecelakaan yang mengakibatkan kehilangan banyak darah, malabsorpsi besi, dan menoragia (menstruasi berlebihan), defisiensi besi, asam folat, infeksi HIV, gangguan struktur hemoglobin seperti thalassemia (Masukume et al, 2015). Pada ibu hamil yang anemia harus diketahui secara pasti penyebab anemianya sehingga dapat diberikan intervensi yang tepat.

\section{Dampak Anemia Pada Ibu Hamil dan Janin}

Anemia ringan pada ibu hamil tidak secara langsung berdampak buruk pada kehamilan dan persalinan kecuali cadangan besi dalam tubuh ibu semakin berkurang sehingga anemia berubah menjadi tingkat sedang atau berat. Anemia sedang menyebabkan kelelahan, kekurangan energi, keletihan, dan kinerja yang buruk. Anemia berat berhubungan dengan hasil kehamilan yang buruk, misalnya terjadi palpitasi, takikardi, sesak napas, meningkatkan curah jantung yang dapat ngakibatkan dekompensasi dan gagal jantung yang berakibat fatal, peningkatan insiden persalinan preterm, preeklamsia, dan sepsis (Milman, 2015). Anemia selama kehamilan memunyai implikasi yang negatif pada janin karena anemia dikaitkan 
dengan kerusakan perkembangan otak, BBLR komplikasi bayi lahir preterm, KMK (Kecil Masa Kehamilan), dan IUGR (Masukume et al, 2015; Milman, 2015; Viteri, 2011).

\section{Kandungan Zat Gizi Biskuit Ubi Jalar Ungu Sebagai Alternatif Perbaikan Gizi Di Masyarakat}

Ubi jalar ungu merupakan sumber karbohidrat dan sumber kalori yang cukup tinggi. Ubi jalar ungu juga merupakan sumber vitamin dan mineral, vitamin yang terkandung dalam ubi jalar antara lain vitamin A, vitamin C, thiamin (vitamin B1) dan ribovlavin. Sedangkan mineral dalam ubi jalar ungu di antaranya adalah zat besi $(\mathrm{Fe})$, fosfor $(\mathrm{P})$ dan kalsium $(\mathrm{Ca})$. Kandungan lainnya adalah protein, lemak, serat kasar dan abu.

Pigmen warna ungu pada ubi jalar ungu bermanfaat sebagai antioksidan karena dapat menyerap polusi udara, racun, oksidasi dalam tubuh, dan menghambat pengumpulan sel-sel darah. Ubi ungu juga mengandung serat pangan alami yang tinggi, prebiotik. Kandungan lainnya dalam ubi jalar ungu adalah betakaroten. Semakin pekat warna ubi jalar, maka semakin pekat betakaroten yang ada di dalam ubi jalar. Betakaroten selain sebagai pembentuk vitamin A, juga berperan sebagai pengendalian hormon melatonin.

Dalam hal ini, potensi sumber daya alam khususnya pemanfaatan ubi jalar ungu, maka pada penelitian ini peneliti akan membuat diversifikasi pangan lokal yaitu biskuit ubi jalar ungu dengan menganalisis kandungan zat gizi karbohidrat, protein, lemak, zat besi (Fe), vitamin $\mathrm{C}$ (Asam Askorbat) dan uji organoleptik guna memberikan alternatif perbaikan gizi pada masyarakat.

Dengan adanya kandungan karbohidrat pada biskuit ubi jalar ungu, maka biskuit tersebut dapat digunakan sebagai alternatif dan makanan tambahan meskipun memiliki kandungan karbohidrat yang tergolong rendah. Namun dapat kita penuhi dengan konsumsi makanan lainnya karena fungsi utama karbohidrat sebagai zat sumber energi (Amriani, 2017).

\section{Kandungan Zat Gizi Roti Rumput Laut Lawi-Lawi Subtitusi Tempe Sebagai Alternatif Perbaikan Gizi Masyarakat}

Zat gizi merupakan komponen kimia dalam pangan yang dibutuhkan untuk kenormalan fungsi tubuh, hidup sehat, cerdas dan produktif. Definisi ilmu gizi adalah ilmu yang mempelajari zat pangan yang bermanfaat bagi perkembangan dan prestasi manusia, proses yang terjadi pada pangan sejak dikonsumsi, dicerna, diserap, sampai digunakan oleh tubuh dan dampaknya terhadap pertubuhan, perkembangan, produktivitas kerja dan kelangsungan hidup, serta faktor yang memengaruhinya (Pakar Gizi Indonesia, 2014).

Caulerpa racemosa atau dikenal dengan nama lawi-lawi oleh masyarakat sekitar adalah salah satu jenis dari rumput laut yang dikembangkan di Sulawesi Selatan (Mukarramah et al., 
2017). Kabupaten di Sulawesi Selatan yang paling banyak menyumbang produksi rumput laut pada tahun 2013 adalah Kabupaten Takalar sebanyak 580,394.40 ton, disusul oleh Luwu sebanyak 544,563.10 ton, dan Luwu Timur sebanyak 242,421.40 ton. (Badan Pusat Statistik Sulawesi Selatan, 2015).

Rumput laut lawi-lawi memiliki kandungan gizi yang cukup tinggi sebagai sumber protein nabati maupun mineral. Jenis rumput laut ini, mengandung protein $17-27 \%$, lemak $0,08-1,9 \%$, karbohidrat $39-50 \%$, serat 1,3 -12,4\%, dan kadar abu 8,15-16,9\% serta kadar air yang tinggi $80-90 \%$ (Burhanuddin, 2014).

Tempe juga merupakan bahan pangan lokal yang memiliki nilai gizi tinggi. Setiap 100 gram tempe mengandung protein 20,8 gram, lemak 8,8 gram, serat 1,4 gram, kalsium $155 \mathrm{mg}$, fosfor $326 \mathrm{mg}$, zat besi $4 \mathrm{mg}$, vitamin B1 0,19 mg,dan karoten $34 \mu \mathrm{g}$ (Bastian et al., 2013). Menurut Kristianto, Arsinah dan Wahyu (2015: 198), dari sudut kesehatan tempe bermanfaat untuk mencegah terjadinya masalah gizi, bukan hanya kekurangan gizi tetapi juga kelebihan gizi karena protein yang terdapat dalam tempe sangat tinggi dan mudah dicerna (Humaera, 2018).

Pemanfaatan rumput laut dan tempe dapat dimaksimalkan dengan diversifikasi produk olahan yang merupakan salah satu upaya untuk meningkatkan daya guna dan nilai ekonomis dari rumput laut. Salah satu usaha diversifikasi tersebut adalah dengan cara mengolah rumput laut jenis Ceulerpa menjadi produk olahan makanan. Salah satu jenis produk makanan yang saat ini sering dikonsumsi di masyarakat mulai dari anak-anak hingga dewasa adalah roti.

Nilai energi Rumput laut Ceulerpa racemosa kebanyakan di kontribusikan oleh karbohidrat dan protein karena nilai total lipid rendah (2,06\% DW). Oleh karena itu, alga ini cocok sebagai makanan diet untuk menurunkan obesitas ( Mukarramah et al., 2017).

\section{Pemberdayaan Masyarakat Dalam Upaya Pencegahan Anemia}

Keterlibatan masyarakat sebagai komunitas tempat tinggal ibu hamil tentunya sangat diperlukan dalam upaya pencegahan dan penanganan anemia pada ibu hamil, salah satu upaya untuk meningkatkan kualitas hidup ibu hamil adalah terbentuknya satu dukungan dari masyarakat. Dengan demikian, kontribusi keluarga sebagai pemberi perawatan dan penguatan kapasitas kader kesehatan merupakan hal yang sangat penting. Kurang terpaparnya masyarakat dan kader kesehatan mengenai anemia pada ibu hamil diprediksi menjadi penyebab kurangnya dukungan sosial terhadap klien dengan anemia pada ibu hamil. Dukungan tersebut akan muncul seiring dengan meningkatnya pengetahuan dan sikap masyarakat terhadap masalah anemia pada ibu hamil. 
Oleh karena itu, perlu dilakukan suatu kegiatan untuk meningkatkan pemberdayaan masyarakat melalui kader kesehatan dalam mengenal, mencegah dan menangani anemia pada ibu hamil sehingga dukungan sosial berbasis masyarakat dapat ditingkatkan. Melalui upaya keterlibatan dan pemberdayaan masyarakat (kader kesehatan) ini diharapkan dukungan dalam upaya pencegahan dan penanganan anemia pada ibu hamil dapat meningkat (Sukmawati, 2018). 


\section{DAFTAR PUSTAKA}

Almatsier S. (2009). Prinsip Dasar Ilmu Gizi. PT. Jakarta: Gramedia Pustaka Utama. Amriani, A. (2017). Analisis Kandungan Zat Gizi Biskuit Ubi Jalar Ungu (Ipomoea Batatas L. Poiret) sebagai Alternatif Perbaikan Gizi di Masyarakat (Doctoral dissertation, Universitas Islam Negeri Alauddin Makassar).

Bastian, F, dkk. Daya Terima dan Kandungan Zat Gizi Formula Tepung Tempe dengan Penambahan Semi Refined Carrageenan (Src) dan Bubuk Kakao. Jurnal Aplikasi Teknologi Pangan Vol. II No. I. Makassar: Prodi Teknologi Pangan UNHAS, 2013.

Burhanuddin. Respon Warna Cahaya terhadap Pertumbuhan dan Kandungan Karatenoid Anggur Laut (Caulerpa racemosa) pada Wadah Terkontrol. Jurnal Balik Diwa Vol. V No. 1. Makassar: Prodi Budidaya Perairan UNISMUH Makassar, 2014.

Creasy RK, Robert R, Jay D, Charles JL, and Thomas RM. (2009). Maternal fetal Medicine Principles and Practice 6Edition. Philadelphia: Saunders Elsevier.

Humaerah, A. M. (2018). Analisis Kandungan Zat Gizi Roti Rumput Laut Lawi-lawi (Ceulerpa racemosa) Subtitusi Tempe sebagai Alternatif Perbaikan Gizi Masyarakat (Doctoral dissertation, Universitas Islam Negeri Alauddin Makassar).

Jufar, AH and Tewabech Z. (2014). Prevalence of Anemia Among Pregnant Women Attending Antenatal Care at Tikur Anbessa Specialized Hospital Addis Ababa Ethiopia. Journal of Hematology and Thromboembolic Disease 2014, 2 (1): 1-6.

Krisnawati, N. Hubungan tingkat konsumsi dengan anemia dan KEK pada ibu hamil di Puskesmas Wonoayu Kabupaten Sidoarjo (2010). Surabaya.

Kristiyanasari, Weni. 2010. Gizi Ibu Hamil. Yogyakarta: Nuha Medika.

Kristianto, Yohanes, Arsinah Habibah Fitriah dan Wahyu Dwi Astuti. Budaya Pengolahan Produk Tempe Generasi Dua di Sentra Industri Kerajinan Tempe Kota Malang. Buletin Penelitian Sistem Kesehatan Vol. XVIII No. 2. Malang: Politeknik Kesehatan Kementerian Kesehatan Malang, 2015.

Morrison JC and Marc RPJ. (2011). Anemia Associated with Pregnancy. Global Libary of Women's Medicine 2011 DOI 10.3843/ GLOWM.10164. Diakses: 5 Januari 2016.

Mubarak WI. (2007). Promosi Kesehatan Untuk Kebidanan. Jakarta : Graha Ilmu. Marmi NU dan Raharjo B. (2012). Aspek Dasar Kependidikan. Jakarta: Bina Aksara. Masukume G, Ali SK, Louise CK, Philip NB, and Gill N. (2015). Risk Factors and Birth Outcomes of Anaemia in Early Pregnancy in a Nulliparous Cohort. PLOS ONE 10 (4). 
Mukarramah dkk. Low Fat High Protein Sosis Berbahan Dasar Lawi-Lawi (Caulerpa racemosa) sebagai Inovasi Kuliner Sehat Khas Makassar dan Makanan Alternatif bagi Anak Penderita Obesitas. Makassar: Hasanuddin Student Journal Vol. I No. 1, 2017.

Purwaningtyas, M. L., \& Prameswari, G. N. (2017). Faktor kejadian anemia pada ibu hamil. HIGEIA (Journal of Public Health Research and Development), 1(3), 43-54.

Prahesti, R. (2017). Analisis Faktor-Faktor Yang Berhubungan Dengan Kejadian Anemia Pada Ibu Hamil Di Puskesmas Prambanan, Sleman, Yogyakarta. Surakarta: Pasacasarjana Universitas Sebelas Maret.

Prawirohardjo S. (2007). Ilmu Kebidanan. Jakarta: Yayasan Bina Pustaka.

Proverawati, A. (2011). Anemia dan Anemia Kehamilan. Yogyakarta: Nuha Medika.

Sharma, JB and Meenakshi S. (2010). Anemia in Pregnancy. JIMSA OctoberDesember 2010 23 (4):253-260.

Solehati, T., Sari, C. W. M., Lukman, M., \& Kosasih, C. E. (2018). Pengaruh Pendidikan Kesehatan Terhadap Pengetahuan Deteksi Dini Dan Pencegahan Anemia Dalam Upaya Menurunkan AKI Pada Kader Posyandu. Jurnal Keperawatan Komprehensif (Comprehensive Nursing Journal), 4(1), 7-12.

Sukmawati, S., Mamuroh, L., \& Nurhakim, F. (2018). PEMBERDAYAAN MASYARAKAT DALAM UPAYA PENCEGAHAN DAN PENANGANAN ANEMIA PADA IBU HAMIL DI PUSKESMAS HAURPANGGUNG. Jurnal Pengabdian Kepada Masyarakat, 2(9), 804-807.

Sulistyaningsih \& Yuliyanti. (2017). Penatalaksanaan Pendidikan Kesehatan Diit Anemia Ibu Hamil dengan Masalah Ketidakseimbangan Nutrisi Kurang dari Kebutuhan Tubuh: Indonesian Jurnal On Medical Science (IJMS) Vol.4 No. 1 Januari 2017.

Supariasa, I. D. N., Bakri, B., \& Fajar, I. (2002). Penilaian Status Gizi (2nd ed.). Buku Kedoktran EGC.

Syarfaini, S., Alam, S., Aeni, S., Habibi, H., \& Novianti, N. A. (2020). Faktor Risiko Kejadian Anemia Pada Ibu Hamil Di Wilayah Kerja Puskesmas Sudiang Raya Kota Makassar. Al-sihah: The Public Health Science Journal, 11(2).

Tarwoto dan Wasnidar. (2007). Anamia pada Ibu Hami, Konsep dan Penatalaksanaanya. Jakarta: Trans Info Media.

Wiknjosastro H. (2006). Ilmu Kebidanan. Jakarta: Yayasan Bina Pustaka Sarwono Prawirohardjo. 